\title{
Research Article \\ Effect of Indole-3-Butyric Acid on Clonal Propagation of Swietenia macrophylla through Branch Cutting
}

\author{
Md. Salim Azad and Md. Abdul Matin \\ Forestry and Wood Technology Discipline, Khulna University, Khulna 9208, Bangladesh \\ Correspondence should be addressed to Md. Salim Azad; azadfwt@yahoo.com
}

Received 7 July 2015; Accepted 21 October 2015

Academic Editor: Tariq Mahmood

Copyright (C) 2015 Md. S. Azad and Md. A. Matin. This is an open access article distributed under the Creative Commons Attribution License, which permits unrestricted use, distribution, and reproduction in any medium, provided the original work is properly cited.

\begin{abstract}
The study discloses the scopes of clonal propagation Swietenia macrophylla through branch cutting treated with IBA. A total of four hundred cuttings were used with four replications to assess the rooting ability. The study exposed significant $(p<0.5)$ difference of rooted cuttings among the treatments. The highest (62.51\%) rooting percent was observed in cutting with $0.4 \%$ IBA treatment. In addition, root number and its length per cutting were increased with increasing IBA concentration $(p<0.5)$. The experiment showed significant $(p<0.5)$ difference of sprouting among the treatments. The highest $(67.27 \%)$ percent of sprouting was observed in cuttings with $0.4 \%$ solution, which showed a similar fashion of percent of rooting. The study also showed significant $(p<0.5)$ difference of shoot number per cutting, the length of the longest shoot, and number of leaves per cutting among the treatments. The overall survival of rooted cuttings after transfer to polybag significantly $(p<0.5)$ differed among the cuttings treated with different IBA solution. The highest survival percentage (69.67\%) was observed in the cuttings rooted with $0.4 \%$ IBA treatment and the lowest (55.6\%) survival was found in cuttings treated with control. The use of $0.4 \%$ IBA treatment is suggested for rooting of juvenile leafy branch cutting of $S$. macrophylla.
\end{abstract}

\section{Introduction}

Swietenia macrophylla King, big-leaved mahogany, a timber species of the greatest economic value of Maliaceae family, is indigenous to the mainland of Central and South America, from Mexico to Peru, Bolivia, and Brazil, which makes it the most extensively dispersed mahogany species [1-3]. It is an exotic tree species in Bangladesh and becoming close to nature in some part of domestication. It was first introduced in Indian subcontinent in 1872 from Brazil [3, 4]. S. macrophylla, one of the significant commercially important neotropical timber species [5], grows well from sea level to $1500 \mathrm{~m}$ altitude where annual rainfall is between 1400 and $2500 \mathrm{~mm}$ with a mean annual temperature of $20-28^{\circ} \mathrm{C}$. The plantation of $S$. macrophylla performed better on deep, nutrient rich, well drained soil with a $\mathrm{pH}$ range of 6.5 to 7.5 but it cannot tolerate water logged conditions. It can be found on alluvial, volcanic, lateritic soils, heavy clays, and soil derived from limestone, granite, and other types of rocks and even on shallow rendzinas within its natural range of habitat [3]. S. macrophylla is considered as luxurious timber species for high class furniture and cabinet manufacturing. The bark has been used as a febrifuge and also for dying and tanning leather [3]. The seed of this species is used for extracting oil which is edible and performs antimalarial, antibabesial, and antidiarrhoeal activities [6]. The seed of this species is used as a popular ingredient of cardiac and blood sugar reducing medicines [7]. Raw seeds of S. macrophylla are used for diabetes and hypertension treatment in many countries. Traditionally, seeds are chewed or crushed and swallowed in India and in Malaysia for those purposes [8]. This is also practiced in Bangladesh (personal observation). Antioxidant, antidiabetic, anti-inflammatory, antimutagenic and antitumor and antifungal, and antihyperglycaemic activities have been reported in many research articles of this species $[6,7,9,10]$.

Clonal propagation proposes the prospects, changes, and opportunities to generate a dependable and sufficient supply 
of better-quality planting stock locally, timely, and quickly. Various tropical tree species have been fruitfully propagated by branch cuttings [11]. This approach is painstaking the model system for a quick development $[12,13]$ through maintaining certain desirable traits of a threatened species at a low cost using nonmist propagator [14], although many species differ in their rooting requirements [15] and rooting success differs with different concentrations of individual auxins $[14,16]$. In addition, age of cutting and donor plant also influences over the rooting ability of cuttings. Usually the more juvenile the cuttings, the greater the success in rooting [17-22]. Moreover, rooting success, rooting speed, root length, and root number reduce with increasing the magnitude of maturity of donor plant [21, 22]. But no serious attempt was taken to propagate Swietenia macrophylla. So, it is crucial to determine the appropriate treatment for optimum rooting of this species for vegetative propagation. This species is very important from different points of view (ecological, economical, aesthetic, etc.) for Bangladesh. Indigenous species are being replaced by exotic fast-growing species in the rehabilitation of degraded tropical forests. A remarkable number of species are required to restore degraded ecosystems properly, particularly in the tropics. However, the irregular flowering and fruiting habits and the recalcitrant nature of the seeds of many species make seed collection problematic. To overcome the unpredictable supply of seeds, many studies have been conducted to investigate the ability of cuttings to propagate and successful rooting has recently been reported for a considerable number of Southeast Asian rainforest species [23]. Bangladesh initiates vegetative propagation for tree improvement since 1977. Several methods including side veneer and whiptongue grafting, forkert, Patch and T-budding, and adult and juvenile and nonleafy cuttings and air layering have been tried on 15 forest species but the success varied among the species [24]. Vegetative reproduction could open up a new horizon for the multiplication of species for large-scale plantations [25]. The species which propagated by vegetative propagation can show disease resistant property because they are the same genotype as the mother plant. For short rotation and industrial species vegetative propagation is an alternative option [26] for conservation. With an aim to assist preserving this species from economic and biodiversity points of view, this experiment was designed to investigate the possibility of vegetative propagation of Swietenia macrophylla by investigating the effects of different IBA concentrations on the rooting ability of juvenile branch cuttings from mother tree. Several studies of $S$. macrophylla have been conducted (Table 1) but studies related to macro vegetative propagation especially rooting of branch cutting are very scant. Therefore, an attempt was taken to carry on this experiment. The aim of this study was to explore the scope of clonal propagation of Swietenia macrophylla by branch cutting. The main objectives of this study were (i) to find out the effect of IBA treatment on rooting and sprouting ability in juvenile stem cutting and (ii) to examine the survival percentage of rooted cuttings treated with different IBA concentration.
TABLE 1: Study of seed germination, seedling growth, and propagations related with Swietenia macrophylla.

\begin{tabular}{lcc}
\hline Research study & Using parts & References \\
\hline $\begin{array}{l}\text { Seed viability } \\
\text { (tetrazolium test) }\end{array}$ & Seeds & {$[5,28,29]$} \\
$\begin{array}{l}\text { Cryopreservation } \\
\text { Seed germination } \\
\text { (presowing treatment) }\end{array}$ & Seed & {$[30]$} \\
Seedling growth & Seeds & {$[3,5,28,31]$} \\
$\begin{array}{l}\text { Growth response } \\
\text { (to biofertilizers) }\end{array}$ & Seedlings & {$[3,31]$} \\
Biomass estimation & Stem cutting & {$[32]$} \\
$\begin{array}{l}\text { Macropropagation } \\
\text { (in mist propagator) }\end{array}$ & Shoot & {$[33]$} \\
In vitro propagation & Stem cutting & {$[34]$} \\
In vitro propagation & Tissue culture (seed) & {$[36]$} \\
In vitro propagation & Tissue culture (shoot) & {$[37]$} \\
Somatic embryogenesis & Embryo & {$[38]$} \\
\hline
\end{tabular}

\section{Materials and Methods}

2.1. Study Site. The experiment was conducted in the forest nursery of Forestry and Wood Technology Discipline, Khulna University, Bangladesh. The study area is a low ( $4 \mathrm{~m}$ above the sea level) fertile floodplain dominated by alluvial soils [27]. The geographic position of the study area is $22.802^{\circ} \mathrm{N}$ latitude and $89.533^{\circ} \mathrm{E}$ longitude. The landscape of the study area is located in the southwestern part of Bangladesh near the Sundarbans, the largest unit mangrove forest in the world. The climate of this area is documented as subtropical in nature, in particular winter (NovemberFebruary), summer (March-mid-June), and monsoon (late June-September), the distinguishing seasons, approximately similar to the other parts of the country. In winter the temperature variation is very low $\left(7\right.$ to $\left.12^{\circ} \mathrm{C}\right)$ but in summer it rises from 25 to $32^{\circ} \mathrm{C}$. Sometimes it might be increased up to $40^{\circ} \mathrm{C}$ [27].

2.2. Construction of Propagator. The experiment on clonal propagation was carried out in a low cost nonmist propagator. The propagator was constructed of wooden frames and lined with transparent polythene sheet described by Leakey et al. [14] and modified by Kamluddin et al. [39]. The structure was rectangular (length: $1.8 \mathrm{~m} \times$ width: $1 \mathrm{~m} \times$ height: $1.5 \mathrm{~m}$ ) in shape covered with white polythene sheet and closely fitted with a lid, so that the lid was completely airtight. The whole structure was placed on the concrete floor of the nursery. The base of the structure was completely watertight. The polythene base of the propagator was covered with $10 \mathrm{~cm}$ thick layer of moist coarse sand mixed with successive layers of fine gravels and small stones. This layer acted as rooting media supported by perforated plastic tray. The propagator was kept under the shade to avoid excessive heat accumulation. Mean temperature within the propagator during rooting was maintained between 25 to $32^{\circ} \mathrm{C}$. To facilitate gas exchange, the propagator was opened for a short time in the morning 
TABLE 2: Effect of IBA on rooting ability, sprouting ability, and overall survival of rooted cuttings of S. macrophylla.

\begin{tabular}{lcccc}
\hline \multirow{2}{*}{ Parameters } & & \multicolumn{2}{c}{ IBA concentration (treatments) } \\
& Control (T0) & $0.2 \%$ IBA (T1) & $0.4 \%$ IBA (T2) & $0.8 \%$ IBA (T3) \\
\hline Rooting (\%) & $37.24 \pm 0.37 \mathrm{a}$ & $55.30 \pm 1.64 \mathrm{~b}$ & $62.51 \pm 2.84 \mathrm{~b}$ & $43.21 \pm 1.54 \mathrm{a}$ \\
Number of roots per cutting & $1.26 \pm 0.26 \mathrm{a}$ & $2.25 \pm 0.24 \mathrm{a}$ & $5.73 \pm 1.31 \mathrm{~b}$ & $6.68 \pm 1.79 \mathrm{~b}$ \\
Longest root (cm) & $1.56 \pm 0.28 \mathrm{a}$ & $3.28 \pm 0.31 \mathrm{a}$ & $7.66 \pm 1.42 \mathrm{~b}$ & $14.22 \pm 1.88 \mathrm{c}$ \\
Sprouting (\%) & $34.52 \pm 3.12 \mathrm{a}$ & $56.23 \pm 2.31 \mathrm{~b}$ & $67.27 \pm 27 \mathrm{~b}$ & $45.42 \pm 1.79 \mathrm{a}$ \\
Number of sprouts per cutting & $1.72 \pm 0.36 \mathrm{a}$ & $2.86 \pm 0.43 \mathrm{ab}$ & $4.16 \pm 0.85 \mathrm{bc}$ & $4.81 \pm 0.84 \mathrm{c}$ \\
Longest sprouts (cm) & $8.21 \pm 1.62 \mathrm{a}$ & $14.16 \pm 1.91 \mathrm{~b}$ & $15.34 \pm 1.76 \mathrm{~b}$ & $15.51 \pm 1.86 \mathrm{~b}$ \\
Number of leaves per cutting & $6.72 \pm 1.28 \mathrm{a}$ & $7.51 \pm 1.32 \mathrm{a}$ & $10.43 \pm 1.85 \mathrm{~b}$ & $10.74 \pm 1.03 \mathrm{~b}$ \\
Survival (\%) & $55.60 \pm 1.31 \mathrm{a}$ & $67.54 \pm 2.10 \mathrm{~b}$ & $69.67 \pm 1.54 \mathrm{~b}$ & $62.21 \pm 1.81 \mathrm{~b}$ \\
\hline
\end{tabular}

Note: \pm indicates mean \pm standard error and the same letter(s) indicate(s) no significant difference at $p<0.05$.

and in the late afternoon. When the lid of the propagator was opened for inspection, a fine jet of water spraying was used to maintain a low vapor pressure deficit inside the propagator for a enduringly humid environment throughout the propagation period. Air temperature both inside and outside the rooting tent was measured by the thermometers.

2.3. Cutting Materials and Design of the Experiment. Twentyfive mother trees were identified and tagged at home gardens of Jessore, Bangladesh. A total of sixteen healthy branch cuttings per mother trees of closely uniform sized (on average $12-15 \mathrm{~cm}$ in length) with one or two leaves trimmed with scissors up to fifty percent of total leaf area were collected from 6- to 10-year-old candidate plus trees for the assessment of rooting behavior of juvenile branch cuttings. Cuttings were then enclosed with polythene bags to protect moisture loss and were then quickly transported to the propagation site. Mother trees, length, and diameter of cuttings were indifferent among the treatments to avoid the variation other than treatments. The cuttings were then immersed shortly in Dithane M45 solution to avoid fungal diseases and kept under shade for thirty minutes in open air. The cuttings were treated with four treatments of indole 3-butyric acid (IBA) solution for a moment. The treatments were T0 (control), T1 $(0.2 \%$ IBA), T2 (0.4\% IBA), and T3 (0.8\% IBA). The treated cuttings were placed in the propagator with completely randomized design. Twenty-five cuttings were used with four replications in each treatment. So a total of $400(25 \times 4 \times 4)$ cuttings were placed under four different treatments with four replications.

2.4. Observation on Budding and Rooting. The assessments of rooting success were carried out weekly after the first two weeks of cutting placement in the propagator. A cutting was considered as rooted when it had at least one root exceeding $1 \mathrm{~cm}$ long. The rooting of cuttings in the propagator completed within six weeks after putting the cuttings into the rooting media in propagator. The cuttings were subjected to weaning before transferring them into polybag. For weaning, the propagator was kept open at night every alternate day for a week and then every night for another three days. This process was also carried out every alternate day for a week at day time and then every day for another three days to harden the rooted cuttings in prevailing adverse environment outside the propagator. All the rooted cuttings were transferred into polybags filled with a mixture of forest soil and decomposed cow-dung in a ratio of $3: 1$. The observations on sprouting, rooting, number of sprouts/roots/leaves per cuttings, and length of the longest root and shoot were recorded before planting the rooted cutting into polybags. The rooted cuttings were then allowed to grow for ninety days in open sun to count the survival percentages. Watering was done once a day at late afternoon. Weeding was done when necessary. No additional fertilizer and pesticide were used.

2.5. Data Analysis. Statistical analysis was done by using MS Excel 2007, Statistical Package SPSS (v 16.0). Rooting, sprouting, and survival ability were expressed in percent. Descriptic statistics for quantitative parameters were carried out with Kaleidagraph (version 4). One-way analysis of variance (ANOVA) was done to test the significant difference among the treatment effects on number of rooted cuttings, shooted cuttings, number of roots per cuttings, number of sprouts per cutting, number of leaves per cuttings, and survival of transplanted cuttings. Tukey's Post Hoc tests were carried out for comparison of means of different particulars of various treatments. Prior to analyze ANOVA, the data recorded in percent were applied arcsine transformation to obtain normally distributed data.

\section{Results}

3.1. Rooting Ability of Cuttings. The cuttings of S. macrophylla rooted well (Figure 1) in the present study. Rooting percent was varied from 37.24 to $62.51 \%$ among the various IBA treatments. The highest rooting percent was observed in $0.4 \%$ IBA concentration (T2) and lowest rooting percent was observed in control (T0) (Figure 2). The rooting percent was significantly $(p<0.05)$ increased with the IBA treatment (Table 2). Again the number of roots per cutting was significantly $(p<0.05)$ increased with increasing the concentration of IBA. The highest average number of roots per cutting was observed to be 6.68 in $0.8 \%$ IBA and the lowest average number of roots per cutting was observed to be 1.26 in control. The average longest root was also significantly $(p<0.05)$ increased with increasing the concentration of IBA. The average longest root was observed to be $1.56 \mathrm{~cm}$, 


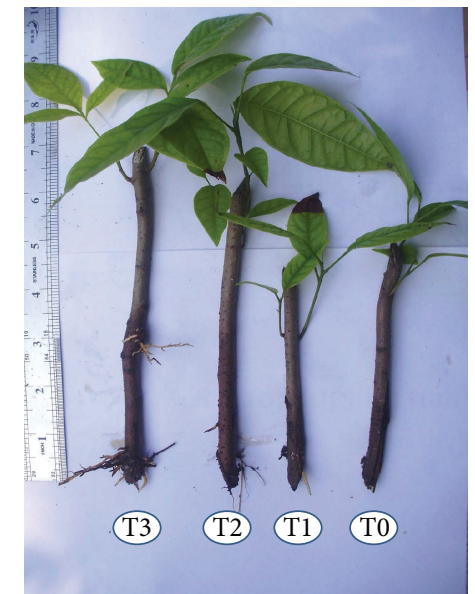

FIGURE 1: Rooting ability of Swietenia macrophylla stem cutting under various IBA treatments.

$3.28 \mathrm{~cm}, 7.66 \mathrm{~cm}$, and $14.12 \mathrm{~cm}$ in control, $0.2 \%$ IBA, $0.4 \%$ IBA, and $0.8 \%$ IBA treatments, respectively (Table 2 ).

3.2. Sprouting Ability of Cuttings. The cuttings of $S$. macrophylla sprouted well (Figure 1) also in the present study. Sprouting percent was varied from 34.52 to $67.27 \%$ among the various IBA treatments. The highest sprouting percent was observed in $0.4 \%$ IBA concentration (T2) and lowest sprouting percent was observed in control (T0) (Figure 2). The sprouting percent was significantly $(p<0.05)$ increased with the IBA treatment (Table 2). Again the number of sprouts per cutting was significantly $(p<0.05)$ increased with IBA concentration. The highest average number of sprouts per cutting was observed to be 4.81 in $0.8 \%$ IBA and the lowest average number of sprouts per cutting was observed to be 1.72 in control. The average longest root was also significantly $(p<0.05)$ increased with increasing the concentration of IBA. The average longest sprout was observed to be $8.21 \mathrm{~cm}, 14.16 \mathrm{~cm}, 15.34 \mathrm{~cm}$, and $15.51 \mathrm{~cm}$ in control, $0.2 \% \mathrm{IBA}, 0.4 \% \mathrm{IBA}$, and $0.8 \%$ IBA treatments, respectively. The average number of leaves per cutting was also significantly $(p<0.05)$ increased with IBA treatment (Table 2). The average number of leaves per cutting was 6.72 , $7.51,10.43$, and 10.74 in control, $0.2 \%$ IBA, $0.4 \%$ IBA, and $0.8 \%$ IBA treatments, respectively (Table 2).

3.3. Survival of Rooted Cuttings. The overall survival of rooted cuttings was very high 90 days after transplanting from propagator to polybag. The rooted cuttings treated with IBA significantly $(p<0.05)$ increased the overall survival of the rooted cutting (Table 2). The highest survival was found to be $69.67 \%$ in $0.4 \%$ IBA treatment and the lowest survival of $55.6 \%$ was found in control (Figure 2).

\section{Discussion}

The use of different rooting hormones for the protocol development of stem/branch cuttings of forest tree species

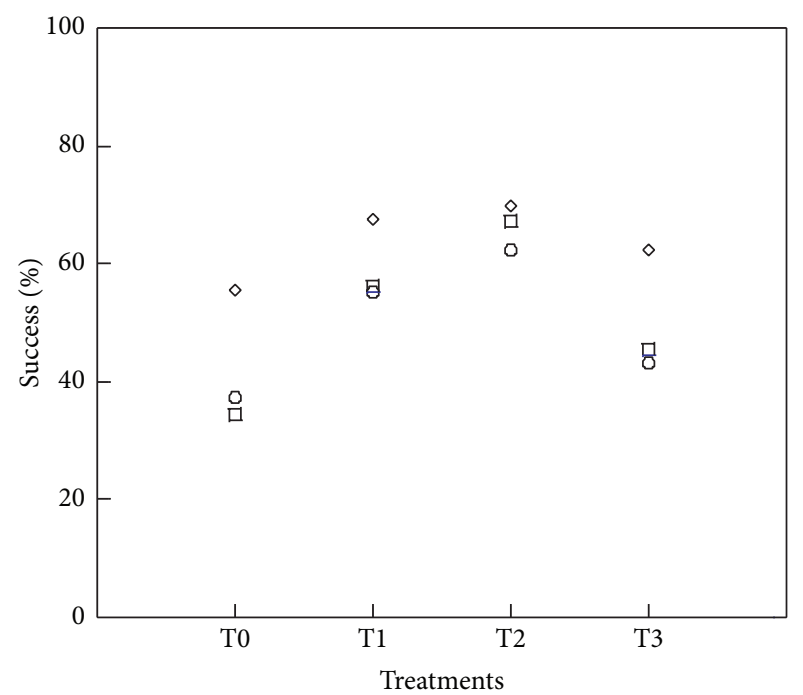

$$
\begin{aligned}
& \diamond \text { Rooting success } \\
& \square \text { Sprouting success } \\
& \diamond \text { Survival success }
\end{aligned}
$$

FIGURE 2: Rooting, sprouting, and survival success of Swietenia macrophylla stem cutting under various IBA treatments.

is widely documented [14, 17, 40-45]. Husen and Pal [17] investigated the effect of age of donor plants and use of auxins on rooting in single noded leafy stem cuttings of teak (Tectona grandis). They also carried out another study on effect of branch position and auxin treatment on clonal propagation of Tectona grandis [43]. The rooting hormone applied for cuttings, especially IBA, has a significant importance in rooting of various tropical forest tree species [13, 16, 17, 43-49]. Berhe and Negash [48] reported rooting response through branch cutting of Juniperus procera by using IAA, IBA, and NAA. Negash [49] conducted a successful clonal propagation on threatened Juniperus procera by using different concentrations of IBA. Amri et al. [18] investigated the effects of age of donor plant, IBA treatment, and cutting position on rooting ability of stem cuttings on Dalbergia melanoxylon. But the concentration of using IBA for rooting ability varied among species. In our present study, we observed that highest rooting percent with the application of $0.4 \%$ IBA also revealed no significant difference between using $0.2 \%$ IBA and $0.4 \%$ IBA on rooting percent but further increase of IBA concentration $(0.8 \%)$ lead to decreasing the percent of rooting. The study revealed very much similar result with Abdullah et al. [44]. They observed highest percent of rooting of Psidium guajava with the application of $0.2-0.4 \%$ IBA but it reduced with increasing of IBA concentration. The similar results were also observed by Aminah et al. [50] on Shorea leprosula rooting percent. They noticed that the application of IBA significantly increased the rate of root emergence in single noded leafy stem cutting. This result is a contrast to Opuni-Frimpong et al. [19]. They observed that rooting percent of Khaya anthotheca and Khaya ivorensis increased with increasing IBA concentration. Ofori et al. [47] observed that IBA has no overall effects on rooting percentage on Milicia excelsa through leafy stem cuttings but they found a strong negative 
correlation $(r=0.90, p<0.05)$ between rooting percentage and auxin concentration. Baul et al. [51] found the highest rooting percentage for $0.4 \%$ IBA concentration followed by control on Stereospermum suaveolens. Higher rooting percent for our concerned species under low IBA concentration may be due to the higher level of endogenous auxin content in the cuttings. Hartmann et al. [52] documented variation of auxin content at time of severance.

The present study revealed significant difference of average number of roots per cutting and the length of longest root with increasing IBA concentration. Abdullah et al. [44] also found similar trend of rooting ability on Psidium guajava. Various studies on Dalbergia melanoxylon [18], Tectona grandis [43], and Juniperus procera [49] also documented significant difference of root number per cutting among IBA treatments. Husen and Pal [43] documented rooting and sprouting percent, mean leaves number, mean shoots number, and shoot and leaf length, and mean number of roots and length per cutting were significantly influenced by the branch position and auxin treatment on Tectona grandis. Negash [49] observed significant difference of root number per cutting among the IBA treatment. He noticed that the number of rooted cuttings and the subsequent root number declined quickly when cutting was treated with $0.4 \%$ IBA. He also noticed that mean root number increased over threefold in cutting treated with $0.4 \%$ IBA. In contrast, several studies on Pausinystalia johimbe [13] and Holarrhena pubescens [45] documented no significant difference of root number per cutting and the length of roots with IBA treatments. Ofori et al. [47] noticed that the mean number of roots per cutting was increased with auxin application, but there was no significant difference among the IBA treatments. It may be due to the fact that the content of endogenous auxin in the stem cuttings of some species decreases when taken from mature mother trees which may lead to reducing rooting ability $[17,45]$. Baul et al. [51] reported that the differences in mean root number per rooted cutting on Stereospermum suaveolens were not statistically significant among IBA treatment $(p>0.1)$ but the length of the longest root for all treatment was statistically significant $(p<0.05)$.

The present study documented the highest percent of sprouting with $0.4 \%$ IBA treatment but number of sprouts per cutting and the length of longest sprout significantly increased with increasing IBA concentration. The average number of leaves per cutting also followed similar fashion. The consequence of auxin in promoting rooting of cuttings is well recognized [11, 16, 18, 43-49] whereas very few documents are available on the effectiveness of IBA in relation to sprouting. However Husen and Pal [43] carried out an experiment on effect of branch position and auxin treatment on clonal propagation of Tectona grandis and found similar results of highest percent of sprouts and the length of sprouts in $0.4 \%$ IBA treatment. They also found similar trends in relation to leaves number per cuttings.

The present study revealed that the survival of rooted cutting after transfer to polybag was significantly higher for the cutting treated with $0.4 \%$ IBA which is very much similar with the findings of Baul et al. [45] for Tectona grandis but in contrast, Baul et al. [51] on Stereospermum suaveolens and Minadawati and Rostawati [53] on Agathis loranthifolia documented highest survival percent with low concentration of IBA $(0.2 \%)$ treatments. It may be due to the fact that the application of higher concentration of IBA treatments seems to be detrimental for survival for some species. Baul et al. [45] postulated that higher concentration of IBA treatment may have some negative impacts against naturally occurring growth hormones in the cuttings.

\section{Conclusion}

Swietenia macrophylla is very important from ecological, economical, aesthetic point of view for Bangladesh and clonal propagation through branch cutting might be effective method for its conservation. The present study highlights IBA treatments for maximum rooting, sprouting response, and survival of rooted cutting after transfer to polybag. The highest percent of rooting and sprouting was significantly higher in cuttings treated $0.4 \%$ IBA while number of roots per cutting, length of the longest root, number of sprouts per cutting, longest sprouts, and number of leaves per cutting were higher at $0.8 \%$ IBA treatment. But there is no significant difference with $0.4 \%$ IBA treatment expect in number of sprouts per cuttings. Survival of rooted cutting after transfer to polybag was significantly higher in cuttings with $0.4 \%$ IBA treatment. Therefore, considering all the results under different treatments, we recommended that branch cutting with $0.4 \%$ IBA treatment may be applicable for this species. However the genetic constituents in the propagules could be determined for future study.

\section{Conflict of Interests}

The authors declare that there is no conflict of interests concerning the publication of this paper.

\section{Authors' Contribution}

Md. Salim Azad and Md. Abdul Matin performed equally in experimental design and paper writing. Comprehensive data analysis was done by Md. Salim Azad.

\section{Acknowledgments}

The authors acknowledge the owner of the home garden for providing them the access to his garden and to collect the juvenile branch cutting for the study. They also acknowledge the staffs of Forestry and Wood Technology Discipline, Khulna University, Bangladesh, for the contribution of propagator construction and support during the experiments.

\section{References}

[1] F. B. Lamb, Mahogany of Tropical America: Its Ecology and Management, University of Michigan Press, Ann Arbor, Mich, USA, 1966.

[2] L. K. Snook, "Catastrophic disturbance, logging and the ecology of mahogany (Swietenia macrophylla King): grounds for listing 
a major tropical timber species in CITES," Botanical Journal of the Linnean Society, vol. 122, no. 1, pp. 35-46, 1996.

[3] R. H. M. J. Lemmens, "Swietenia macrophylla King," in Prota 7(1): Timbers/Bois Duvre 1, D. Louppe, A. A. Oteng-Amoako, and M. Brink, Eds., PROTA, Wageningen, The Netherlands, 2005.

[4] J. S. Gamble, A Manual of Indian Timbers, International Book Distributors, Dehradun, India, 1985.

[5] J. E. Mayhew and A. C. Newton, The Silviculture of S. macrophylla, CABI Publishing, New York, NY, USA, 1998.

[6] M. Dutta, U. Raychaudhuri, R. Chakraborty, and D. Maji, "Role of diet and plants on diabetic patients-a critical appraisal," Scientific and Culture, vol. 77, no. 3-4, pp. 115-122, 2011.

[7] M. Dutta, U. K. Biswas, R. Chakraborty et al., "Antidiabetic and antioxidant effect of Swietenia macrophylla seeds in experimental type 2 diabetic rats," International Journal of Diabetes in Developing Countries, vol. 33, no. 1, pp. 60-65, 2013.

[8] K. C. Chan, T. S. Tang, and H. T. Toh, "Isolation of swietenolide diacetate from Swietenia macrophylla," Phytochemistry, vol. 15, no. 3, pp. 429-430, 1976.

[9] A. P. Guevera, A. Apilado, H. Sakarai, M. Kozuka, and H. Tokunda, "Anti-inflammatory, antimutagenecity and antitumor activity of mahagony seeds Swietenia macrophylla (Meliaceae)," The Philippine Journal of Science, vol. 125, pp. 271-278, 1996.

[10] M. A. Hashim, M. F. Yam, S. Y. Hor, C. P. Lim, M. Z. Asmawi, and A. Sadikun, "Anti-hyperglycaemic activity of Swietenia macrophylla King (meliaceae) seed extracts in normoglycaemic rats undergoing glucose tolerance tests," Chinese Medicine, vol. 8, article 11, 2013.

[11] Z. Tchoundjeu, E. K. Asaah, P. Anegbeh et al., "Putting participatory domestication into practice in west and central Africa," Forests, Trees and Livelihoods, vol. 16, no. 1, pp. 53-69, 2006.

[12] H. T. Hartmann, D. E. Kester, F. T. Davies, and R. L. Geneve, Plant Propagation: Principles and Practices, Prentice Hall, Inc., Upper Saddle River, NJ, USA, 7th edition, 2006.

[13] Z. Tchoundjeu, M.-L. N. Mpeck, E. Asaah, and A. Amougou, "The role of vegetative propagation in the domestication of Pausinystalia johimbe (K. Schum), a highly threatened medicinal species of West and Central Africa," Forest Ecology and Management, vol. 188, no. 1-3, pp. 175-183, 2004.

[14] R. R. B. Leakey, J. F. Mesen, Z. Tchoundjeu et al., "Lowtechnology techniques for the vegetative propagation of tropical trees," Commonwealth Forestry Review, vol. 69, no. 3, pp. 247257, 1990.

[15] R. R. B. Leakey, A. C. Newton, and J. M. P. Dick, "Capture of genetic variation by vegetative propagation: processes determining success," in Tropical Trees: The Potential for Domestication and the Rebuilding of Forest Resources, R. R. B. Leakey and A. C. Newton, Eds., pp. 72-83, HMSO, London, UK, 1994.

[16] Z. Tchoundjeu, M. L. Avana, R. R. B. Leakey et al., "Vegetative propagation of Prunus africana: effects of rooting medium, auxin concentrations and leaf area," Agroforestry Systems, vol. 54, no. 3, pp. 183-192, 2002.

[17] A. Husen and M. Pal, "Variation in shoot anatomy and rooting behaviour of stem cuttings in relation to age of donor plants in teak (Tectona grandis Linn. f.)," New Forests, vol. 31, no. 1, pp. 57-73, 2006.

[18] E. Amri, H. V. M. Lyaruu, A. S. Nyomora, and Z. L. Kanyeka, "Vegetative propagation of African Blackwood (Dalbergia melanoxylon Guill. \& Perr.): effects of age of donor plant, IBA treatment and cutting position on rooting ability of stem cuttings," New Forests, vol. 39, no. 2, pp. 183-194, 2010.
[19] E. Opuni-Frimpong, D. F. Karnosky, A. J. Storer, and J. R. Cobbinah, "Key roles of leaves, stockplant age, and auxin concentration in vegetative propagation of two African mahoganies: Khaya anthotheca Welw. and Khaya ivorensis A. Chev," New Forests, vol. 36, no. 2, pp. 115-123, 2008.

[20] B. Singh, R. Yadav, and B. P. Bhatt, "Effects of mother tree ages, different rooting mediums, light conditions and auxin treatments on rooting behaviour of Dalbergia sissoo branch cuttings," Journal of Forestry Research, vol. 22, no. 1, pp. 53-57, 2011.

[21] R. M. Girourd, "Rooting plain and heel cuttings of spruce," Commenwealth Forest Review, vol. 50, no. 1, pp. 28-31, 1971.

[22] R. M. Girourd, "Propagation of spruce by stem cutting," New Zealand Journal of Forestry Research, vol. 4, pp. 140-149, 1973.

[23] J. M. P. Dick and H. Aminah, "Vegetative propagation of tree species indigenous to Malaysia," The Commonwealth Forestry Review, vol. 73, no. 3, pp. 164-171, 1994.

[24] M. G. Kibria, D. C. Sarker, M. A. T. Hossain, M. A. Manna, M. A. Motaleb, and S. S. Islam, "Forest Statistics of Bangladesh," Bulletin 4, Forest Economics Division, Bangladesh Forest Research Institute, Chittagong, Bangladesh, 1986.

[25] A. T. M. Abdullah, M. A. Hossain, and M. K. Bhuiyan, "Propagation of Latkan (Baccaurea sapida Muell. Arg.) by mature stem cutting," Research Journal of Biological Sciences, vol. 1, no. 2, pp. 129-134, 2005.

[26] M. K. Alam, Rural Homesteads: Potential Areas for Production and Conservation of Medicinal Plants in Bangladesh, Bangladesh Forest Research Institute, Chittagong, Bangladesh, 2001.

[27] BBS, Bangladesh Population Census, Zilla Series: Khulna, Bangladesh Bureau of Statistics, Statistics Division, Ministry of Planning, Government of Bangladesh, 2001.

[28] L. Schmidt and D. Jøker, "Swietenia macrophylla King," Seed Leaflet 30, Danida Forest Seed Centre, Copenhagen, Denmark, 2000.

[29] D. Blakesley, S. Elliott, C. Kuarak, P. Navakitbumrung, S. Zangkum, and V. Anusarnsunthorn, "Propagating framework tree species to restore seasonally dry tropical forest: implications of seasonal seed dispersal and dormancy," Forest Ecology and Management, vol. 164, no. 1-3, pp. 31-38, 2002.

[30] M. Marzalina and M. N. Normah, "Cryopreservation techniques for the long-term storage of mahogany Swietenia macrophylla seeds," Journal of Tropical Forest Science, vol. 14, no. 4, pp. 525-535, 2002.

[31] G. P. Bauer and J. K. Francis, "Swietenia macrophylla King: honduras mahogany," Caoba USDA Forest Service, SO-ITFSM-81, p. 7, 1998.

[32] Y. A. Tarranco-Castañeto, "Growth response of Mahogany (Swietenia macrophylla King) cuttings to applied Mykovam and Biocore," in Proceedings of the 12th World Forestry Congress, Québec, Canada, September 2003.

[33] W. C. Adinugroho and K. Sidiyasa, "Model pendugaan biomasa pohon mahoni (Swietenia Macrophylla King) di atas permukaan tanah," Jurnal Penelitian Hutan dan Konservasi Alam, vol. 3, no. 1, pp. 103-117, 2006.

[34] T. Bevu, "Cutting propagation of Mahogany (Swietenia macrophylla King)," Pacific Islands Forests and Trees, no. 4, pp. 13-14, 1999.

[35] J. M. F. C. Brunette, W. C. Otoni, A. L. Pinheiro, and É. P. Fonsica, "Calogênese in vitro em segmentos de epicótilo de mogno (Swietenia macrophylla King) com uso de 6-benzilaminopurina e ácido $\alpha$-naftalenoacético," Scientia Forestalis, vol. 71, pp. 19-24, 2006. 
[36] E. de Souza Schottz, A. N. K. Filho, A. L. Tracz, H. Koehler, L. L. F. Ribas, and M. Quoirin, "Multiplicacão in vitro de Swietenia macrophylla King (Meliaceae) a partir de material juvenile," Ciência Florestal, vol. 17, no. 2, pp. 109-117, 2007.

[37] M. A. Amin, "In vitro propagation of Swietenia macrophylla King," Research Journal of Agriculture and Biological Science, vol. 8, no. 2, pp. 282-287, 2002.

[38] T. E. Maruyama, "Polyethylene glycol improves somatic embryo maturation in big-leaf mahogany (Swietenia macrophylla King, Meliaceae)," Bulletin of Forestry and Forest Products Research Institute, vol. 8, pp. 167-173, 2009.

[39] M. Kamluddin, M. Ali, and M. K. Bhuiyan, "Effect of auxin on rooting and growth of stecklings of jackfruit (Artocarpus heterophyllus)," Chittagong University Studies Part II: Science, vol. 20, no. 1, pp. 71-75, 1996.

[40] Z. Tchoundjeu and R. R. B. Leakey, "Vegetative propagation of Lovoa trichilioides: effects of provenance, substrate, auxins and leaf area," Journal of Tropical Forest Science, vol. 13, no. 1, pp. 116$129,2001$.

[41] A. Husen, "Effect of IBA and NAA treatments on rooting of Rauvolfia serpentine Benth. ex Kurz shoot cuttings," Annals of Forest Science, vol. 11, no. 1, pp. 88-93, 2003.

[42] A. Husen, R. Khali, S. Nautiyal, and H. C. S. Bhandari, "Effects of phytohormones on rooting of nodal shoot cuttings of Grewia optiva Drummond," Indian Forester, vol. 129, pp. 1147-1152, 2003.

[43] A. Husen and M. Pal, "Effect of branch position and auxin treatment on clonal propagation of Tectona grandis Linn. f.," New Forests, vol. 34, no. 3, pp. 223-233, 2007.

[44] A. T. M. Abdullah, M. A. Hossain, and M. K. Bhuiyan, "Clonal propagation of guava (Psidium guajava Linn.) by stem cutting from mature stockplants," Journal of Forestry Research, vol. 17, no. 4, pp. 301-304, 2006.

[45] T. K. Baul, M. Mezbahuddin, M. M. Hossain, M. Mohiuddin, and T. K. Baul, "Vegetative propagation of Holarrhena pubescens, a wild tropical medicinal plant: effect of indole-3butyric acid (IBA) on stem cuttings," Forestry Studies in China, vol. 12, no. 4, pp. 228-235, 2010.

[46] R. R. B. Leakey, J. M. P. Dick, and A. C. Newton, "Stock plant derived variation in rooting ability: the source of physiological youth," in Proceedings of the Symposium on Mass Production Technology for Genetically Improved Fast Growing Forest Tree Species, pp. 171-178, Bordeaux, France, September 1992.

[47] D. A. Ofori, A. C. Newton, R. R. B. Leakey, and J. Grace, "Vegetative propagation of Milicia excelsa by leafy stem cuttings: effects of auxin concentration, leaf area and rooting medium," Forest Ecology and Management, vol. 84, no. 1-3, pp. 39-48, 1996.

[48] D. Berhe and L. Negash, "Asexual propagation of Juniperus procera from Ethiopia: a contribution to the conservation of African pencil cedar," Forest Ecology and Management, vol. 112, no. 1-2, pp. 179-190, 1998.

[49] L. Negash, "Successful vegetative propagation techniques for the threatened African pencil cedar (Juniperus procera Hoechst. ex Endl.)," Forest Ecology and Management, vol. 161, no. 1-3, pp. 53-64, 2002.

[50] H. Aminah, J. Mc. P. Dick, R. R. B. Leakey, J. Grace, and R. I. Smith, "Effect of indole butyric acid (IBA) on stem cuttings of Shorea leprosula," Forest Ecology and Management, vol. 72, no. 2-3, pp. 199-206, 1995.

[51] T. K. Baul, M. Mezbahuddin, and M. Mohiuddin, "Vegetative propagation and initial growth performance of Stereospermum suaveolens DC., a wild tropical tree species of medicinal value," New Forests, vol. 37, no. 3, pp. 275-283, 2009.

[52] H. T. Hartmann, D. E. Kester, and F. T. Davies, Plant Propagation, Principles and Practices, Prentice-Hall Inc, New Jersey, NJ, USA, 1990.

[53] N. Minadawati and T. Rostawati, "The influence of container size and color on growth of Agathis loranthifolia seedlings," Buletin Penelitian Hutan, vol. 505, pp. 9-10, 1989. 

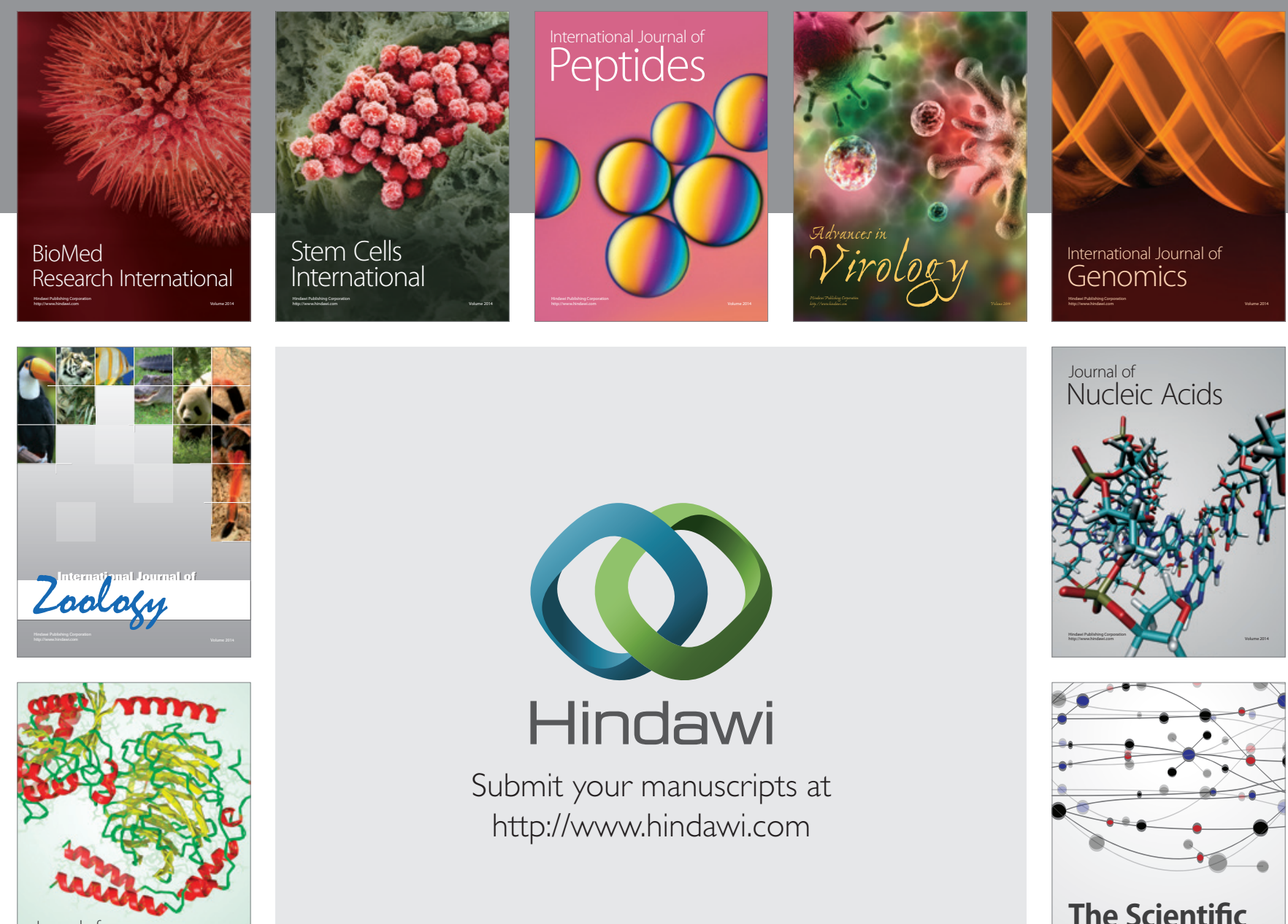

Submit your manuscripts at

http://www.hindawi.com

Journal of
Signal Transduction
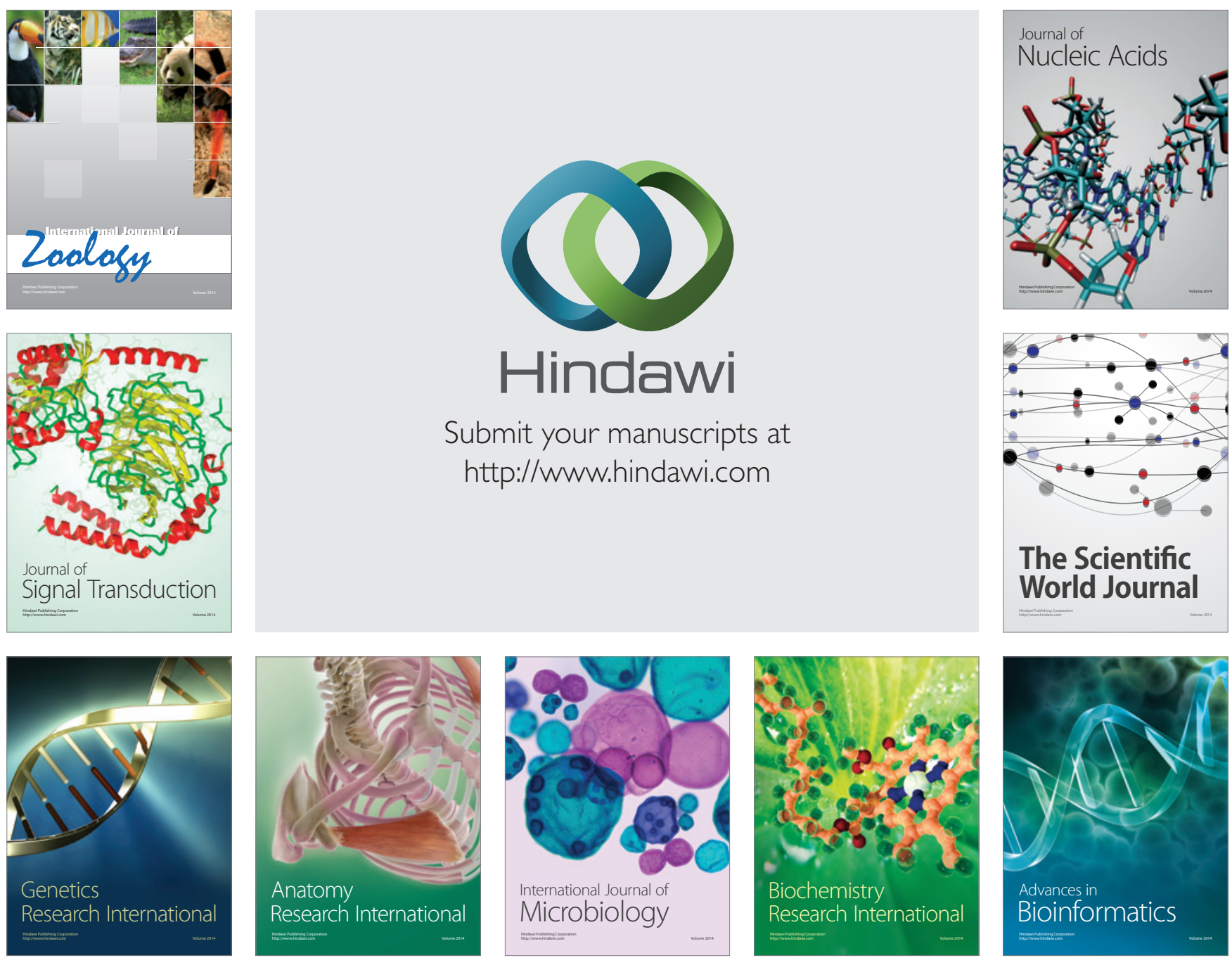

The Scientific World Journal
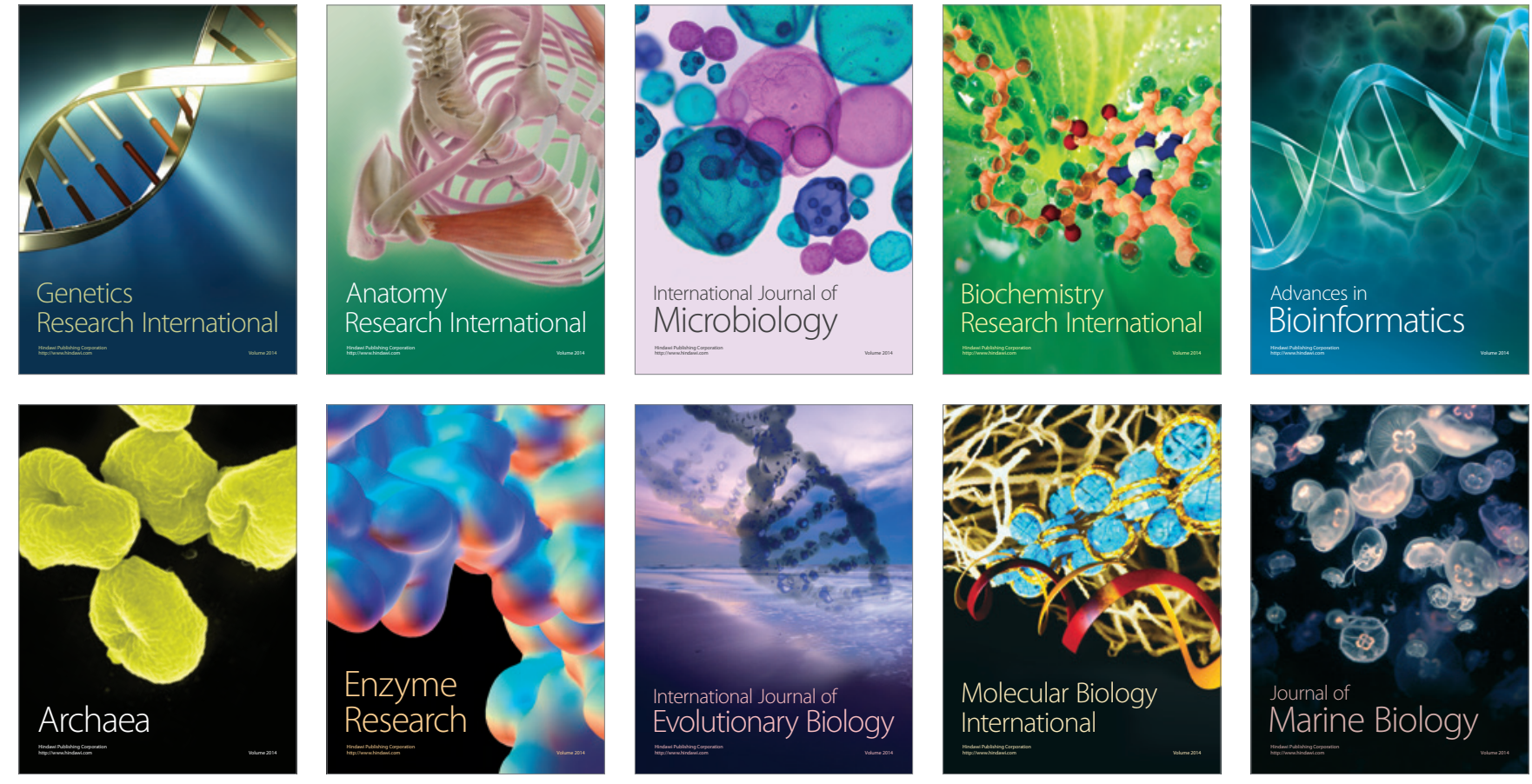